\title{
A Monte Carlo study of contraband detection using fast neutron resonance technique
}

\author{
Jinhyoung Bae, Jooho Whang
}

\author{
Department of Nuclear Engineering, Kyunghee University 1 Sochen-ni, \\ Kihung-eop, Yongin-shi Kyongki-do, 449-701, Korea
}

Fast neutron resonance technique was simulated using MCNP-4B (Monte Carlo N-Parti cle System) to find its usefulness to contraband inspection. By applying neutron techniqu es, elemental composition of the material in question can be characterized, by which existen ce of explosives or narcotics are recognized among many other stuffs being investigated. To obtain fast neutron flux, $D(d, n) 3 H e$ reaction was chosen and using a computer code, DROSG-2000, we produced the flux with variables of energy and neutron radiating angle. Neutron energy range of 2.25 to $5.25 \mathrm{MeV}$, which includes apparent resonance peaks for carbon, oxygen and nitrogen, was applied to the simulation. By moving around the neutron source, a set of a material to be investigated and neutron detector experiences neutrons in the form of narrow line beam with different energies as the angle to the neutron source changes. By positioning the set of the material and detector at several angles, we can obtain the equal number of linear equations to solve as the number of applied angles. Total attenuation of neutron flux obtained at different angles was calculated by using the resul ts of MCNP-4B simulation cases. Among many trials with different number of energy range segmentations and number of element in the material in question, feasible results could be found when the number of elements was five and energy bin was five to nine. More cases when the material in question was mixed or covered with interfering elements such as Al, $\mathrm{Ni}, \mathrm{Cr}, \mathrm{Mn}, \mathrm{Fe}$ and $\mathrm{Si}$ were also simulated to show the increase of relative error up to $50 \%$. More studies to decrease the size of error occurring when the material in question exists with interfering elements and the effects of applying broad beam to the system are required.

Способ резонанса быстрых нейтронов смоделирован с применением системы МонтеКарло MCNP-4B с целью определения его полезности для обнаружения контрабанды. Применение нейтронной техники позволяет охарактеризовать элементный состав исследуемого материала, откуда можно обнаружить наличие взрывчатых веществ или наркотиков среди множества других исследуемых веществ. Для получения потока быстрых нейтронов была выбрана реакция $\mathrm{D}(\mathrm{d}, \mathrm{n}) 3 \mathrm{He}$, и, используя компьютерный код DROSG2000, мы моделировали такой поток с варьированием энергии и угла расхождения нейтронов. При моделировании использовался диапазон энергии нейтронов от 2,25 до $5,25 \mathrm{MэB,} \mathrm{в} \mathrm{пределах} \mathrm{которого} \mathrm{возникают} \mathrm{явные} \mathrm{резонансные} \mathrm{пики} \mathrm{углерода,} \mathrm{кислорода}$ и азота. При перемещении совокупности образца исследуемого материала и детектора нейтронов вокруг источника нейтронов последние детектируются в виде узкого пучка с различной энергией, зависящей от угла поворота относительно источника нейтронов. Располагая совокупность образца исследуемого материала и детектора нейтронов под различными углами, можно получить число линейных уравнений, равное числу упомянутых углов. Полное затухание нейтронного потока, полученного при различных углах, рассчитано с использованием результатов моделирования по MCNP-4В. После множества проб с различными числами энергетических поддиапазонов и числами элементов в исследуемом материале правдоподобные результаты были получены для числа элементов 5 и числа энергетических поддиапазонов от 5 до 9 . Моделированы также дополнительные случаи, когда исследуемый материал смешан или покрыт мешающими элементами, например, $\mathrm{Al}, \mathrm{Ni}, \mathrm{Cr}, \mathrm{Mn}, \mathrm{Fe}$ и $\mathrm{Si}$, и показано, что при этом относительная погрешность возрастает до $50 \%$. Для снижения погрешности, возникающей при совместном присутствии мешающих элементов и исследуемого материала, и выяснения влияния применения широкого пучка необходимы дополнительные исследования. 
In September of 1989 , a horrible accident was occurred where a DC-10 airplane of Union de Transportes Aeriens (UTA) departed from N'Djamena and heading to Charles de Gaulle airport in Paris was ex ploded in the 35,000 feet air by the explosive which is believed to be placed by the Islamic Jihad rebels taking the death toll of 161 people ( 5 crew members and 156 passengers) [1]. Generally, explosives have a higher nitrogen ratio and density, and usually they exist in the form of nitrate $\left(-\mathrm{NO}_{3}\right)$. They also have characteristics of high oxy gen, low hydrogen and carbon content and density of approximately 1.5. A general method to detect such contraband (articles under embargo) is to use X-ray that inter acts with the electrons of the material in question and the attenuation coefficient of $\mathrm{X}$-ray has very close relation to the electron density of the material and the X-ray energy. Major factors attribute to X-ray attenuation are compton scattering and photo electric effect. Although photoelectric ef fect is effective in materials with high atomic number such as metals and inorganic matters, its efficacy decreases as X-ray energy increases. In case of materials with low atomic number such as organic matters, compton scattering plays an important role in X-ray attenuation and it causes far less energy change [2]. With an ordinary X-ray detection method, it is very difficult to clearly identify light elements such as hydrogen, carbon, nitrogen, and oxygen. Thus, technologies to detect contraband using a fast neutron with more than $1 \mathrm{MeV}$ of energy are getting attention. The aim of this study is to distinguish hydrogen, carbon, nitrogen, and oxygen, which are the ele ments of interest contained in contraband goods, and subsequently identify such contraband goods by generating neutrons with 2 6 $\mathrm{MeV}$ of energy and analyzing element specific resonance which depends on the total decrement coefficient of the subject material.

Originally, a fast neutron resonance technology (FNRT) was developed in a labo ratory of Witwatersrand/DeBeers Univer sity (Republic of South Africa) to detect a piece of diamond (approximated diameter of $3 \mathrm{~mm}$ ) inside kimberlite rock. This must be tested using moving conveyer belt. It detects the existence of target material using carbon specific resonance reaction peak within the neutron energy range of 7 8 MeV. In other words, it detects target material by distinguishing carbon specific on-resonance peak from other off-resonance peaks using single peak [3]. Since this method has characteristics that it produces specific resonance for a single element while does not for the other elements, it is difficult to distinguish the peaks when more than two elements are contained in the sample and it has low neutron transmit tance rate. To compensate such disadvantages of the method using a single peak, we choose the energy range where the element of inter est forms broad resonance characteristics.

$D-D$ and $p-T$ nuclear reaction are the most common method to obtain monoener getic neutron source, and for this study, we used DROSG-2000 code and calculated neutron energy distribution, neutron reaction cross section, neutron yield as a function of angle.

To evaluate the feasibility of FNRT as a method to detect explosives we employed TNT, a representative explosive that has been used in the military for more than 100 years, as the subject of this simulation and the simulation was performed using MCNP code. Also the relative errors, which are dependent on the number of element, were analyzed when interfering elements such as $\mathrm{Al}$ and SUS410 were presented in the sample. In addition, with hexamine that has high nitrogen content and polypropylene, a common raw material for plastic, as interfering materials, the relative errors of when TNT was the only subject and when interfering materials were also presented are compared and analyzed.

DROSG-2000 code was used to obtain monoenergetic fast neutron that fits for the aim of this study. This code is comprised of data files contains experimental values obtained from IAEA Nuclear Data Section and it enables us to perform 59 different monoenergetic neutron production simulations [4]. Big-4 reaction is a representative reaction of monoenergetic fast neutron producing nuclear reactions using small accelerators [5]. Among those, D-D and p-T nuclear reactions are fit for this study and they can be described as follow

$$
\begin{aligned}
& { }^{2} \mathrm{H}+d={ }^{3} \mathrm{He}+n+3.269 \mathrm{MeV}, \\
& { }^{3} \mathrm{H}+p={ }^{3} \mathrm{He}+n-0.763 \mathrm{MeV} .
\end{aligned}
$$

In case of D-D nuclear reaction, $Q$ value of the reaction is $3.269 \mathrm{MeV}$ and neutron has a broad energy range as consequence. The range within monoenergetic neutron is produced is $2.45 \sim 7.71 \mathrm{MeV}$. p-T nuclear reaction displays relatively better yield at threshold energy value of 1.148 and 


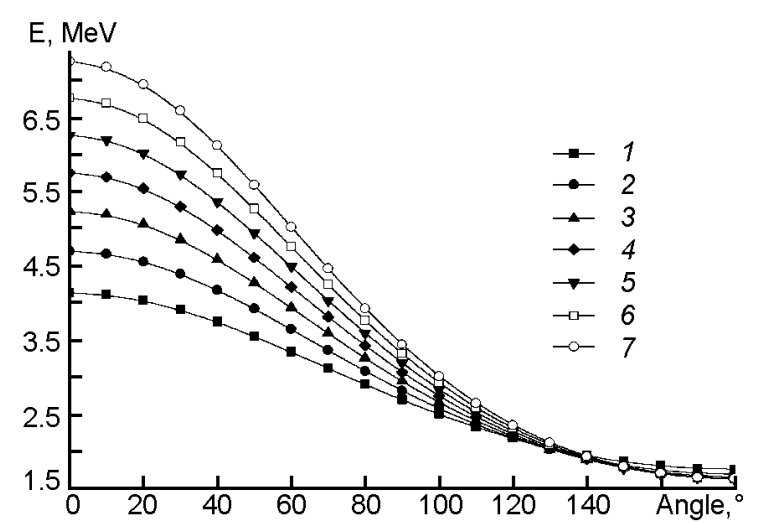

Fig. 1. D-D neutron energy as a function of angle: $1-E_{\mathrm{d}}=1.0 \mathrm{MeV}$;

$$
\begin{array}{ll}
2-E_{\mathrm{d}}=1.5 \mathrm{MeV} ; & 3-E_{\mathrm{d}}=2.0 \mathrm{MeV} ; \\
4-E_{\mathrm{d}}=2.5 \mathrm{MeV} ; & 5-E_{\mathrm{d}}=3.0 \mathrm{MeV} ; \\
6-E_{\mathrm{d}}=3.5 \mathrm{MeV} ; & 7-E_{\mathrm{d}}=4.0 \mathrm{MeV}
\end{array}
$$

8.34 $\mathrm{MeV}$, does not have nuclide residue ex citation, and is a neutron source that produces monoenergetic neutron of few $\mathrm{MeV}$.

Fig. 1, 2 summarize the change of neutron energy as angle changes in D-D and $\mathrm{p}-\mathrm{T}$ reactions. In $\mathrm{D}-\mathrm{D}$ nuclear reaction, when accelerated deuteron has energy range of $1.0 \sim 4.0 \mathrm{MeV}$, neutron has broad energy range of $4.14 \sim 7.26 \mathrm{MeV}$ at $0^{\circ}$ and the range of neutron energy produced is decreases as the angle increases. In case of $\mathrm{p}-\mathrm{T}$ nuclear reaction, when accelerated proton has energy range of $5.0 \sim 8.0 \mathrm{MeV}$, neu tron has energy range of $4.22 \sim 7.23 \mathrm{MeV}$ and $1.28 \sim 2.32 \mathrm{MeV}$ at $0^{\circ}$ and $120^{\circ}$ respectively. Thus it satisfies the purpose of this study. If the target material is thick, accel erated particle loses some energy before it produces neutron. In $D-D$ reaction, neutron displays broad spectrum up to $120^{\circ}$, and narrow spectrum where the angle is greater than $120^{\circ}$. Compared to neutron source of $D-D$ reaction, $\mathrm{p}-\mathrm{T}$ reaction has broader spectrum in general.

The dimension of subject is always limited. Each part of the subject is being probed with neutrons that have different energies and angles. In other words, neutrons display various spectrums at different detectors. The energy of neutron depends on the energy of accelerated particle, and various neutron spectrums are produced at different angles according to thickness of the subject. The energy of neutron also depends on the angle.

The changes of neutron reaction cross section as angle changes in D-D and $p-T$ nuclear reaction are presented in Fig. 3 and 4 , respectively.

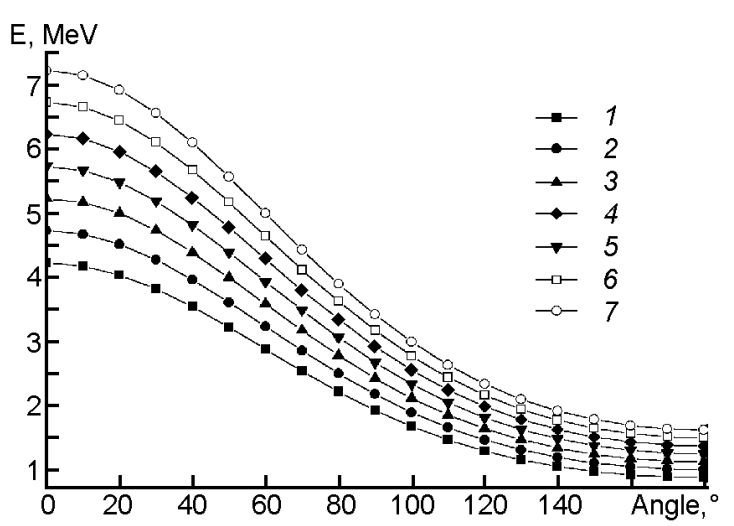

Fig. 2. p-T neutron energy as a function of angle. $\quad 1-E_{\mathrm{p}}=5.0 \mathrm{MeV}$;

$\begin{array}{ll}2-E_{\mathrm{p}}=5.5 \mathrm{MeV} ; & 3-E_{\mathrm{p}}=6.0 \mathrm{MeV} ; \\ 4-E_{\mathrm{p}}=6.5 \mathrm{MeV} ; & 5-E_{\mathrm{p}}=7.0 \mathrm{MeV} ; \\ 6-E_{\mathrm{p}}=7.5 \mathrm{MeV} ; & 7-E_{\mathrm{p}}=8.0 \mathrm{MeV} .\end{array}$

The distribution patterns of neutron reaction cross section in $D-D$ and $p-T$ reaction are different. While $\mathrm{p}-\mathrm{T}$ reaction shows relatively bigger changes of cross section as angle changes, D-D reaction shows no apparent changes of cross section when the angle is greater than $40^{\circ}$, irrespective of the energy of accelerated particle because the energy loss (stopping power) due to in teraction between deuteron beam and the subject is small. The neutron energy spectrum is leveled at any angle. Since the total neutron yield of $D-D$ nuclear reaction is $1.885 \cdot 10^{10}$ neutron $/ \mu \mathrm{A} \cdot \mathrm{s}$ and that of $\mathrm{p}-\mathrm{T}$ nuclear reaction is $1.866 \cdot 10^{11}$ neutron $/ \mu \mathrm{A} \cdot \mathrm{s}$, $\mathrm{p}-\mathrm{T}$ nuclear reaction has higher yield.

Fig. 5 is schematic presentation of FNRT rotational geometry with different angles. Rotational geometry is different from tomography because tomography creates vari ous images with different projections acquired by rotating both the subject and detector, but with this FNRT, neutrons generated by fixed accelerator have various energy spectrums according to their angle of emission. In FNRT method, the subject being probed with neutron comprises an as sembly with detector and rotates at designated angles to produce various images. Fig. 6 shows the total cross section accord ing to neutron energy distribution with dif ferent angles when $E_{d}=2.5 \mathrm{MeV}$ and $\Delta E_{d}=0.6 \mathrm{MeV}$. Although element specific resonance characteristics are observed at various energy ranges, the resonance peaks of different elements are superimposed in most energy ranges. Thus, it is very difficult to determine element composition ratio of a certain material that contains more 


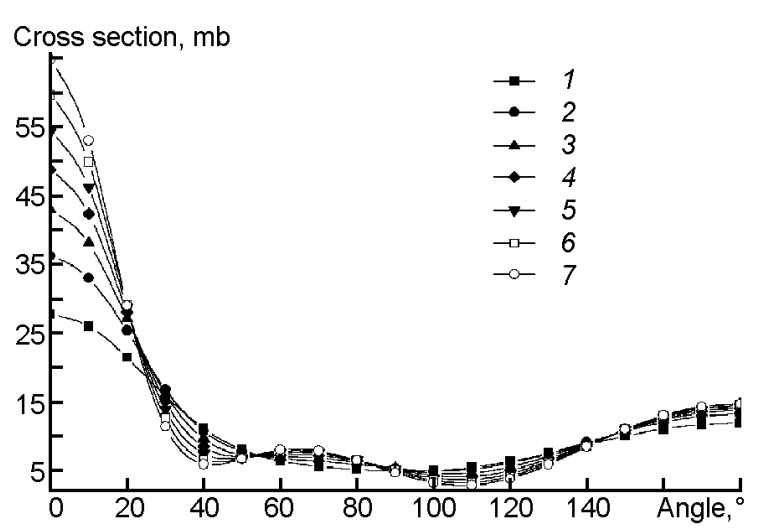

Fig. 3. D-D differential cross section as a function of angle: $\quad 1-E_{\mathrm{d}}=1.0 \mathrm{MeV}$; $2-E_{\mathrm{d}}=1.5 \mathrm{MeV} ; \quad 3-E_{\mathrm{d}}=2.0 \mathrm{MeV}$; $4-E_{\mathrm{d}}=2.5 \mathrm{MeV} ; \quad 5-E_{\mathrm{d}}=3.0 \mathrm{MeV}$; $6-E_{\mathrm{d}}=3.5 \mathrm{MeV} ; \quad 7-E_{\mathrm{d}}=4.0 \mathrm{MeV}$.

than one element. Section 4 discusses about the method to solve this problem.

The governing equation for fast neutron follows exponent decreasing law described as equation (3) below.

$$
N=N_{0} e^{-\mu x}
$$

Where $N, N_{0}, \mu$, and $x$ are the attenuated the neutron number in a small area of the detector, corresponding source neutron number without attenuation, effective attenuation coefficient-cm ${ }^{2}$, and the effective total projected atomic content-\#/cm ${ }^{2}$, respectively. Neutron flux has energy distribution and consequently the attenuation coefficient has a certain relationship to neutron reaction cross section or average neutron reaction cross section but they are not the same. Furthermore, most materials are comprised of more than one element, superimposed resonance peaks occur as in Fig. 6. To compensate this problem, linear attenuation model is employed.

$$
A x=b .
$$

The equation above has limitation to ad dress that total attenuation coefficient is the sum of attenuation coefficients of individual elements and it is difficult to clearly determine element composition ratio of tar get material. Thus, we generated matrix $A$, a pseudo inverse matrix of matrix $A$, calculated attenuation coefficients of individual elements of matrix $A$, then obtained matrix $I_{m \times m}$ by multiplying it by pseudo inverse matrix $A$. We also calculated vector $b$, which represents total attenuation, then finally obtained equation for element component $x=A b$

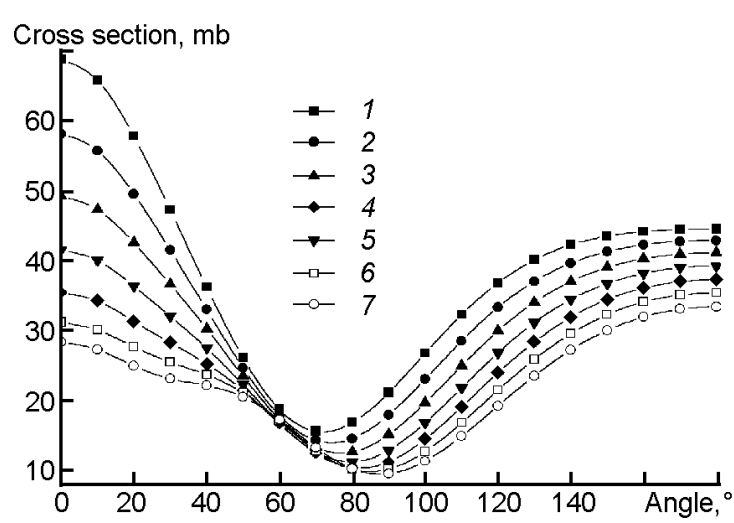

Fig. 4. $p-T$ differential cross section as a function of angle. $\quad 1-E_{\mathrm{p}}=5.0 \mathrm{MeV}$; $2-E_{\mathrm{p}}=5.5 \mathrm{MeV} ; \quad 3-E_{\mathrm{p}}=6.0 \mathrm{MeV}$; $4-E_{\mathrm{p}}=6.5 \mathrm{MeV} ; \quad 5-E_{\mathrm{p}}^{\mathrm{p}}=7.0 \mathrm{MeV}$; $6-E_{\mathrm{p}}=7.5 \mathrm{MeV} ; \quad 7-E_{\mathrm{p}}=8.0 \mathrm{MeV}$.

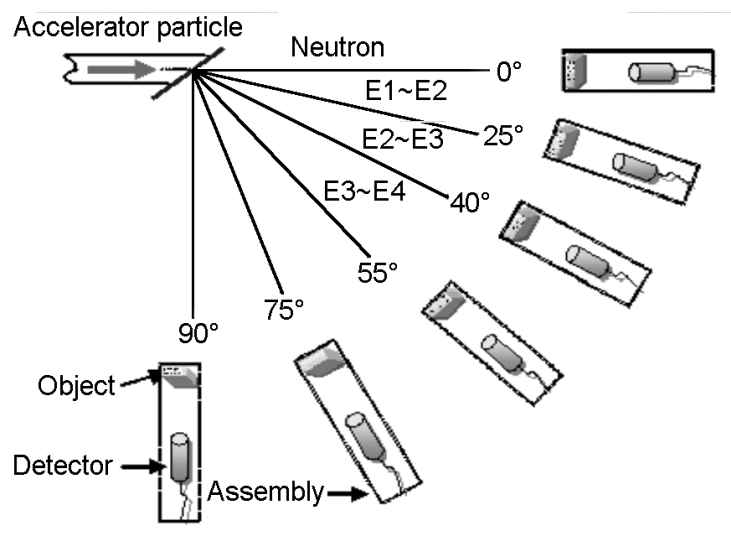

Fig. 5. Rotational geometry.

$$
A_{m \times n} A_{n \times m}^{\uparrow}=I_{m \times m} \rightarrow A_{n \times m} \rightarrow x=A^{\uparrow} b
$$

the following is example of linear equation obtained using 4 different elements in TNT and 12 different energy ranges.

The relative error of solutions obtained by linear equation is calculated using equa tion (6) and (7). Most contraband is composed of hydrogen, carbon, nitrogen, and oxygen, and we calculated two types of relative errors as following. The relative error for carbon, nitrogen, and oxygen is Error3 and that of hydrogen, carbon, nitrogen, and oxygen is Error4. In these equations, $x_{L S}$ is element composition obtained by linear re gression analysis and $x_{i}$ is actual element composition.

$$
=\sqrt{\frac{\text { Error } 3=}{\left.x_{L S C}-x_{t C}\right)^{2}+\left(x_{L S N}-x_{t N}\right)^{2}+\left(X_{L S O}-x_{t O}\right)^{2}}},
$$




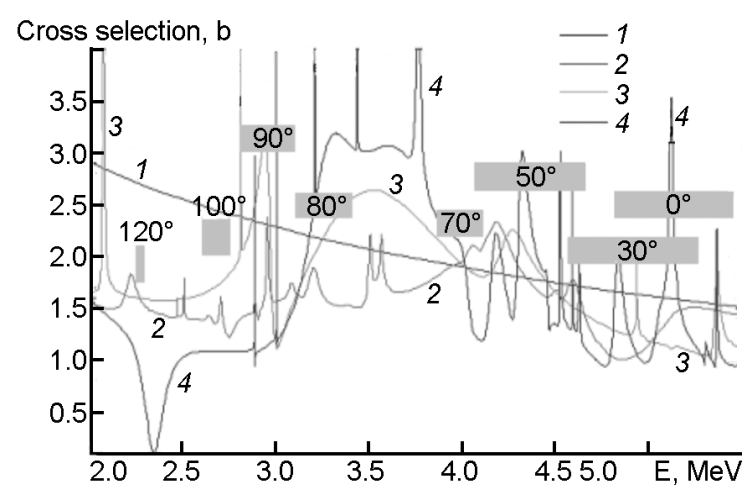

Fig. 6. Neutron energy at different angles.

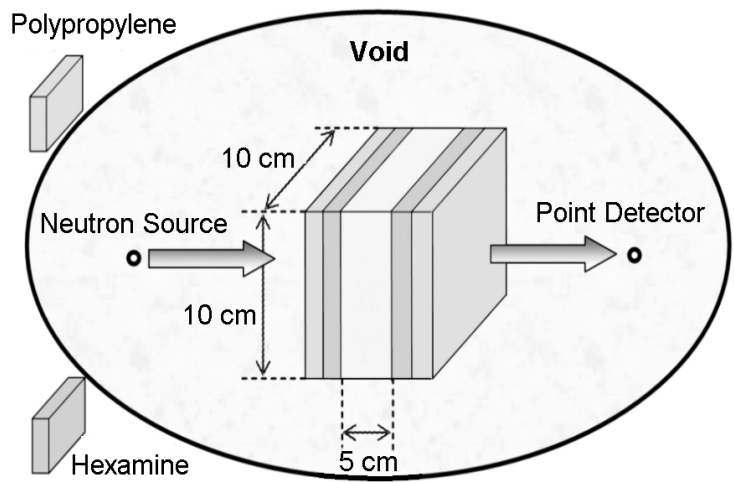

Fig. 7. Simple geometry of MCNP simulation.

1 - Hydrogen; 2 -Nitrogen; 3 - Carbon;

4 - Oxygen.

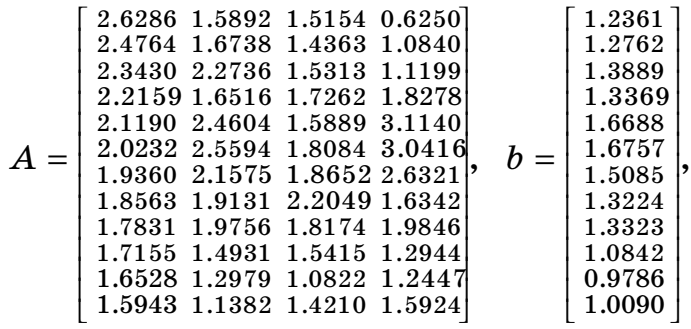

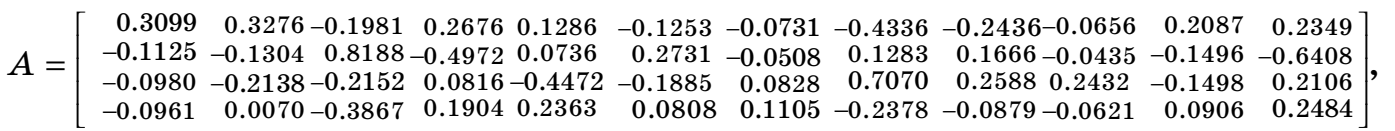

$$
\begin{gathered}
\text { Error4 }=\sqrt{\frac{\left.x_{L S C}-x_{t C}\right)^{2}+\left(x_{L S N}-x_{t N}\right)^{2}+}{\left(x_{L S C}\right)^{2}+\left(x_{L S N}\right)^{2}+\left(x_{L S O}\right)^{2}+\left(x_{L S H}{ }^{2}\right.}}+ \\
+\sqrt{\frac{\left(X_{L S O}-x_{t O}\right)^{2}+\left(X_{L S H}-x_{t H}\right)^{2}}{\left(x_{L S C}\right)^{2}+\left(x_{L S N}\right)^{2}+\left(x_{L S O}\right)^{2}+\left(x_{L S H}{ }^{2}\right.}}
\end{gathered}
$$

MCNP code, a electrical computation code employing Monte Carlo method, is used to calculate transportation of neutron, photon, electron in any three dimensional geometrical structures [6]. TNT, a representative explosive, was used as simulation subject and we divided energy range for each angle to simulate condition as if the subject rotates around neutron source. The whole energy bins are described in Table 1 and we assumed good geometry condition to test the feasibility of FNRT as a method to detect contraband. Geometry we employed for MCNP code simulation is described in Fig. 7.

The energy bins in Table 1 include both narrow resonance peak range of oxygen and broad resonance peak range of nitrogen. Composition of TNT and interfering materi als other than TNT are described in Table 2.

In Fig. 8, attenuation coefficients of hy drogen, carbon, nitrogen, and oxygen when
TNT is $1 \mathrm{~cm}$ thick are listed. When com pared to Fig. 6 showing total neutron cross sections of hydrogen, carbon, nitrogen, and oxygen, we can see that the patterns are very similar.

Also, total attenuation curve of TNT well reflects the reaction cross section val ues of each individual element.

The relative errors according to thick ness of TNT are indicated in Table 3 . The reason element ratio is calculated with oxy gen as a control is because oxygen has high est composition ratio in most explosives. Up to $10 \mathrm{~cm}$ of $\mathrm{TNT}$, relative errors do not exceed $3 \%$.

Table 4 and 5 shows the result of simulation using $1 \mathrm{~cm}$ thick TNT and $0.1 \mathrm{~cm}$ thick $\mathrm{Al}$ and SUS410. Also, Table 6 shows relative errors when TNT is $5 \mathrm{~cm}$ thick and interfering materials are $0.5 \sim 2 \mathrm{~cm}$ thick.

The result of relative error analysis when interfering materials other than TNT are presented is following.

In case of the number of energy bins and that of elements $(m=n)$ are same, when there exists $1 \mathrm{~cm}$ thick TNT and $0.1 \mathrm{~cm}$ thick $\mathrm{Al}$ and SUS410, error3 was $86.8 \%$; 


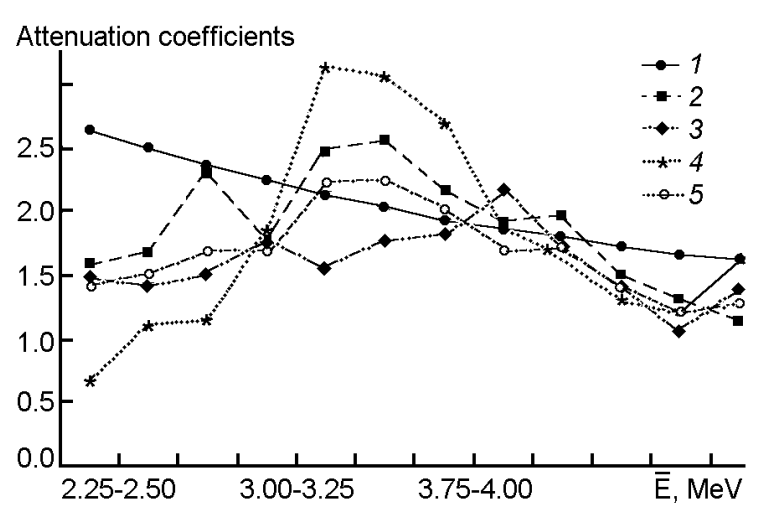

Fig. 8. Attenuation coefficients of TNT (1 $\mathrm{H}, 2-\mathrm{C}, 3-\mathrm{N}, 4-\mathrm{O}, 5-\mathrm{TN})$.

when there exists $1 \mathrm{~cm}$ thick TNT and $0.1 \mathrm{~cm}$ thick SUS410 only, Error3 was $116.9 \%$; when there exists $1 \mathrm{~cm}$ thick TNT and 0.1 thick Al only, error3 was $64.3 \%$. The reason for bigger relative errors is shortage of data redundancy.

Compared to the cases of number of en ergy bin is grater than $6(m>6)$, when the number of energy bin is 6 , relative error was increased because it did not reflect resonance characteristics of hydrogen, carbon, nitrogen, and oxygen correctly.

We could obtain most optimized solutions when hydrogen, carbon, nitrogen, and oxygen were existed only. In other words, in this case, error3 and error4 were minimized. As the number of element increased, distinguishing ability was decreased and such increase worked as an additional factor for errors.

If there existed elements other than hydrogen, carbon, nitrogen, and oxygen, rela tive error increased up to $n=9$ then decreased at $n=10$.
When hexamine that has high nitrogen content and polypropylene, a common raw material for plastic, were existed as interfering materials, the overall relative error was less than $30 \%$.

The aim of this study was to test the feasibility of fast neutron resonance technique as a method to detect contraband. At tenuation coefficients of individual elements and total attenuation were obtained using MCNP code and TNT as subject. The experimental value was compared with the actual element composition ratio of the subject and the relative error was obtained. The feasibility of FNRT as a method to de tect contraband was evaluated by this relative error calculated.

When we divided neutron energy range into 12 bins, the experimental values of composition ratio of $\mathrm{H}, \mathrm{C}, \mathrm{N}$, and $\mathrm{O}$ in TNT were $0.2362,0.3344,0.1423$, and 0.2871 , respectively. Since the actual value were $0.236,0.334,0.143$, and 0.287 , relative error is $0.16 \%$ and this is fairly low. We can obtain most optimized solutions when only four element of $\mathrm{H}, \mathrm{C}, \mathrm{N}$, and $\mathrm{O}$ are presented. In this case we can minimize error3 and error4. Increased number of ele ments works as an additional factor for er rors. We believe when the number of com position element is 5 and the number of energy bin is $5 \sim 9$ is the optimal condition.

For the future, it is required to develop a method to minimize errors of spectrum analysis with various interfering materials and quantitative evaluation method to detect contraband.

Acknowledgement. This work was financially supported by MOCIE through IERC program.

Table 1. Neutron energy bins used [in MeV]

\begin{tabular}{||c|c|c|c|c|c|c|c|c|c|c|c|c||}
\hline $\begin{array}{c}\text { Number } \\
\text { of energy } \\
\text { bins }\end{array}$ & $\begin{array}{c}2.0- \\
2.25\end{array}$ & $\begin{array}{c}2.25- \\
2.5\end{array}$ & $\begin{array}{c}2.5- \\
2.75\end{array}$ & $\begin{array}{c}2.75- \\
3.0\end{array}$ & $\begin{array}{c}3.0- \\
3.25\end{array}$ & $\begin{array}{c}3.25- \\
3.5\end{array}$ & $\begin{array}{c}3.5- \\
3.75\end{array}$ & $\begin{array}{c}3.75- \\
4.0\end{array}$ & $\begin{array}{c}4.0- \\
4.25\end{array}$ & $\begin{array}{c}4.25- \\
4.5\end{array}$ & $\begin{array}{c}4.5- \\
4.75\end{array}$ & $\begin{array}{c}4.75- \\
5.0\end{array}$ \\
\hline 4 & $*$ & $*$ & & & & & & $*$ & & & $*$ & $*$ \\
5 & $*$ & $*$ & & & & $*$ & & $*$ & & & $*$ \\
6 & $*$ & $*$ & & $*$ & & $*$ & & $*$ & & & $*$ & $*$ \\
7 & $*$ & $*$ & $*$ & $*$ & & $*$ & & $*$ & & & $*$ \\
8 & $*$ & $*$ & $*$ & $*$ & & $*$ & & $*$ & & & $*$ & $*$ \\
9 & $*$ & $*$ & $*$ & $*$ & & $*$ & & $*$ & & $*$ & $*$ & $*$ \\
10 & $*$ & $*$ & $*$ & $*$ & & $*$ & $*$ & $*$ & & $*$ & $*$ & $*$ \\
11 & $*$ & $*$ & $*$ & $*$ & & $*$ & $*$ & $*$ & $*$ & $*$ & $*$ & $*$ \\
12 & $*$ & $*$ & $*$ & $*$ & $*$ & $*$ & $*$ & $*$ & $*$ & $*$ & $*$ & $*$ \\
\hline
\end{tabular}


Table 2. Composition of TNT and interfering material

\begin{tabular}{|c|c|c|c|c|c||}
\hline \hline & $\begin{array}{c}\mathrm{TNT} \\
\left(\mathrm{C}_{7} \mathrm{H}_{5} \mathrm{~N}_{3} \mathrm{O}_{6}\right)\end{array}$ & $\begin{array}{c}\text { Hexamine } \\
\left(\mathrm{C}_{6} \mathrm{H}_{12} \mathrm{~N}_{4}\right)\end{array}$ & $\begin{array}{c}\text { Polypropylene } \\
\left(\mathrm{C}_{6} \mathrm{H}_{12} \mathrm{O}_{3}\right)\end{array}$ & $\begin{array}{c}\text { Aluminium } \\
(\mathrm{Al})\end{array}$ & $\begin{array}{c}\text { SUS410 } \\
(\mathrm{Fe}, \mathrm{Ni}, \mathrm{Mn}, \mathrm{Si}, \mathrm{Cr})\end{array}$ \\
\hline $\begin{array}{c}\text { Density }\left(\mathrm{g} / \mathrm{cm}^{3}\right) \\
\text { Atoms } / \mathrm{cm}^{2}\end{array}$ & 1.63 & 1.331 & 0.9 & 2.7 & 7.92 \\
\hline
\end{tabular}

Table 3. Properties and Error4 of TNT

\begin{tabular}{|c|c|c|c|c|c|c|c||}
\hline \hline \multirow{2}{*}{$\begin{array}{c}\text { Thickness } \\
(\mathrm{cm})\end{array}$} & \multicolumn{4}{|c|}{ Weight fraction } & \multicolumn{2}{c|}{ Elemental ratios } & \multirow{2}{*}{ Error 4(\%) } \\
\cline { 2 - 8 } & $\mathrm{H}$ & $\mathrm{C}$ & $\mathrm{N}$ & $\mathrm{O}$ & $\mathrm{C} / \mathrm{O}$ & $\mathrm{N} / \mathrm{O}$ & \\
\hline 1 & 23.6 & 33.5 & 14.2 & 28.7 & 1.17 & 0.50 & 0.16 \\
4 & 23.7 & 33.8 & 13.9 & 28.6 & 1.18 & 0.49 & 1.07 \\
7 & 23.8 & 34.1 & 13.5 & 28.6 & 1.19 & 0.47 & 2.06 \\
10 & 23.8 & 34.4 & 13.2 & 28.6 & 1.20 & 0.46 & 2.98 \\
True value & 23.6 & 33.4 & 14.3 & 28.7 & 1.16 & 0.50 & $*$ \\
\hline \hline
\end{tabular}

Table 4. Error 3 for various combinations of $m$ and $n$

\begin{tabular}{|c|c|c|c|c|c|c|c||}
\hline \multirow{2}{*}{ Number of Elements } & \multicolumn{9}{|c||}{ Energy bins } \\
\cline { 2 - 8 } & 4 bins & 6 bins & 7 bins & 9 bins & 10 bins & 11 bins & 12 bins \\
\hline TNT + Al (5) & 0.551 & 0.177 & 0.200 & 0.233 & 0.235 & 0.237 & 0.237 \\
TNT + SUS410 (9) & 0.942 & 0.412 & 0.391 & 0.487 & 0.584 & 0.488 & 0.502 \\
TNT + Al + SUS410 (10) & 0.716 & 0.285 & 0.321 & 0.416 & 0.422 & 0.418 & 0.426 \\
\hline
\end{tabular}

Table 5. Error 4 for various combinations of $m$ and $n$

\begin{tabular}{|c|c|c|c|c|c|c|c||}
\hline \multirow{2}{*}{ Number of Elements } & \multicolumn{7}{|c||}{ Energy bins } \\
\cline { 2 - 8 } & 4 bins & 6 bins & 7 bins & 9 bins & 10 bins & 11 bins & 12 bins \\
\hline TNT + Al (5) & 0.643 & 0.136 & 0.142 & 0.178 & 0.181 & 0.182 & 0.189 \\
TNT + SUS410 (9) & 1.169 & 0.483 & 0.456 & 0.456 & 0.693 & 0.587 & 0.605 \\
TNT + Al + SUS410 (10) & 0.868 & 0.299 & 0.347 & 0.347 & 0.471 & 0.467 & 0.486 \\
\hline
\end{tabular}

Table 6. Properties and Error of TNT $(5 \mathrm{~cm})$, Hexamine and Polypropylene

\begin{tabular}{|c|c|c|c|c|c|c|c|c|}
\hline \multirow{2}{*}{$\begin{array}{l}\text { Thickness } \\
\text { (cm) }\end{array}$} & \multicolumn{4}{|c|}{ Weight fraction } & \multicolumn{2}{|c|}{ Elemental ratios } & \multirow[t]{2}{*}{ Error $3(\%)$} & \multirow[t]{2}{*}{ Error 4(\%) } \\
\hline & $\mathrm{H}$ & C & $\mathrm{N}$ & $\mathrm{O}$ & $\mathrm{C} / \mathrm{O}$ & $\mathrm{N} / \mathrm{O}$ & & \\
\hline 0.1 & 13.72 & 39.90 & 16.58 & 29.80 & 1.34 & 0.56 & 13.3 & 22.3 \\
\hline 0.2 & 19.67 & 37.57 & 15.57 & 27.19 & 1.38 & 0.57 & 9.43 & 11.5 \\
\hline 0.3 & 24.60 & 35.63 & 14.73 & 25.04 & 1.42 & 0.59 & 9.37 & 8.50 \\
\hline 0.4 & 28.76 & 34.00 & 14.03 & 23.21 & 1.46 & 0.60 & 12.7 & 14.5 \\
\hline 0.5 & 32.30 & 32.60 & 13.43 & 21.67 & 1.50 & 0.62 & 17.2 & 21.4 \\
\hline 0.6 & 35.36 & 31.38 & 12.93 & 20.33 & 1.54 & 0.64 & 22.0 & 27.6 \\
\hline True value & 23.6 & 33.4 & 14.3 & 28.7 & 1.16 & 0.50 & $*$ & $*$ \\
\hline
\end{tabular}




\section{References}

1. J.H.Gibbons, Technology Against Terrorism: The Federal Effort, Washington DC: U.S. Government Printing Office, (1991). http://www.wws.princeton.edu

2. H.Martz, Configuration Management and Performance Verification of Explosives-Detection Systems, The National Academy Press, Washington D.C. (1998). http://www.nap.edu

3. H.Rahmanian, J.I.W.Watterson, Nucl.Instr. and Meth., 139B, 446 (1998).
4. M.Drosg, DROSG-2000: Neutron Source Reactions, Version 2.2, IAEA-NDS-87 (January 2003).

5. J.Csikai, CRC Handbook of Fast Neutron Generators, Vol.I, CRC press, Boca Raton, Florida (1987).

6. J.F.Briesmeister, Ed., A General Monte Carlo N-particle Transport Code (MCNP), Version 4A, LA-12625-M, Los Alamos National Laboratory (1993).

\title{
Дослідження методом Монте-Карло виявлення контрабанди з застосуванням резонансу швидких нейтронів
}

\author{
Чжин Хионг Ба, Чжухо Ванг
}

\begin{abstract}
Спосіб резонансу швидких нейтронів змодельовано з застосуванням системи МонтеКарло МCNP-4В з метою визначення його корисності для виявлення контрабанди. Використання нейтронної техніки дозволяє охарактеризувати елементний склад досліджуваного матеріалу, звідки можна виявити присутність вибухових речовин або наркотиків серед багатьох інших досліджуваних речовин. Для одержання потоку швидких нейтронів було обрано реакцію $\mathrm{D}(\mathrm{d}, \mathrm{n}) 3 \mathrm{He}$, i, користуючись комп'ютерним кодом DROSG-2000, ми моделювали такий потік з варіюванням енергії та кута розходження нейтронів. При моделюванні застосовувався діапазон енергії нейтронів від 2,25 до $5,25 \mathrm{MeB}$, в межах якого виникають явні резонансні піки вуглецю, кисню та азоту. При переміщенні сукупності зразка досліджуваного матеріалу та детектора нейтронів навколо джерела нейтронів останні детектуються у вигляді вузького пучка з різною енергією, що залежить від кута повороту відносно джерела нейтронов. Розташовуючи сукупність образца зразка досліджуваного матеріалу та детектора нейтронів під різними кутами, можна одержати число лінійних рівнянь, яке дорівнює числу згаданих кутів. Повне затухання нейтронного потоку, одержаного при різних кутах, розраховано 3 використанням результатів моделювання за МCNP-4В. Після численних проб з різними числами енергетичних піддіапазонів та числами елементів у досліджуваному матеріалі правдоподобні результати було одержано при числі елементів 5 і числі енергетичних піддіапазонів від 5 до 9. Модельовано також додаткові випадки, коли досліджуваний матеріал змішаний або покритий заважаючими елементами, наприклад, $\mathrm{Al}, \mathrm{Ni}, \mathrm{Cr}$, $\mathrm{Mn}, \mathrm{Fe}$ та $\mathrm{Si}$, і показано, що при цьому відносна похибка зростає до 50 \%. Для зниження похибки, яка виникає у спільній присутності заважаючих елементів та досліджуваного матеріалу, і з'ясування впливу застосування широкого пучка необхідні додаткові дослідження.
\end{abstract}

